\title{
南ミシシッピ大学(The University of Southern Mississippi)の PSRC (Shelby F. Thames Polymer Science Research Center)
}

\section{1. 南ミシシッピ大学の所在地}

南ミシシッピ大学は, アメリカ合衆国ミシシッピ州のハ ティスバーグ (Hattiesburg) という都市にある. ハティ スバーグはミシシッピ州南部に広がるパインベルト地帯の 教育と医療の中心で，人口は 10 万人程度の小都市である. ハティスバーグは州都ジャクソンの南 90 マイル $(145 \mathrm{Km})$, メキシコ湾の北 75 マイル $(120 \mathrm{Km})$, ルイジアナ州ニュー オリンズの北東 105 マイル $(170 \mathrm{Km})$ の位置にあり，複 数の州道が交差している位置にあるためハブシティーとし て近年発展の著しい都市の一つである（図 1). 大学へ行 くには幾つかの手段が考えられるが，2005 年の現時点で は飛行機でニューオリンズまで行き, そこから鉄道かバス またはタクシーなどを利用するのが便利だと思われる.

大学のある州南部は, ミシシッピ川沿いの歴史とメキシ コ湾岸のリゾート地が程よいコンビネーションをつくる地 域といわれている. ハティスバーグは日本の九州南部と同 緯度であり年中温暖な気候であるが，夏場は非常に熱く， メキシコ湾で発生したハリケーンが猛威をふるう事もある. 普段は青い空, 緑の木々や芝が広がる自然豊で綺麗な小都 市である。

\section{2。USM と PSRC の説明}

The University of Southern Mississippi (以下「USM」 と略する)は 1910 年に創立された州立大学である. ハティ スバーグ市内に緑深い 120 万坪 $\left(4 \times 10^{6} \mathrm{~m}^{2}\right)$ の広大なキャ ンパスが広がる. USM は総合大学であり文学, 芸術, 経 済, 教育, 哲学, 科学技術に関した学士課程 67 分野, 修 士課程 48 分野, 博士課程 17 分野を有する. 学生数は 1 万 4000 名，男女比率は 1 対 1 となっている.

USM には「College of Science and Technology」とい う 15 の学科で構成された学部があり, その中に「School of Polymers and High Performance Materials」という高 分子科学に関した学科がある.この学科には, 学部生約 100 名, 大学院生約 80 名, 教官 16 名, スタッフ 16 名が所属

\footnotetext{
* Kurose, Takashi

南ミシシッピ大学 機能高分子材料学科

The University of Southern Mississippi

Polymer Science Research Center, c/o Prof. Otaigbe group (PSRC 235)

118 College Drive \#10076, Hattiesburg, MS 39406-0001, USA 2005.8.9 受理
}

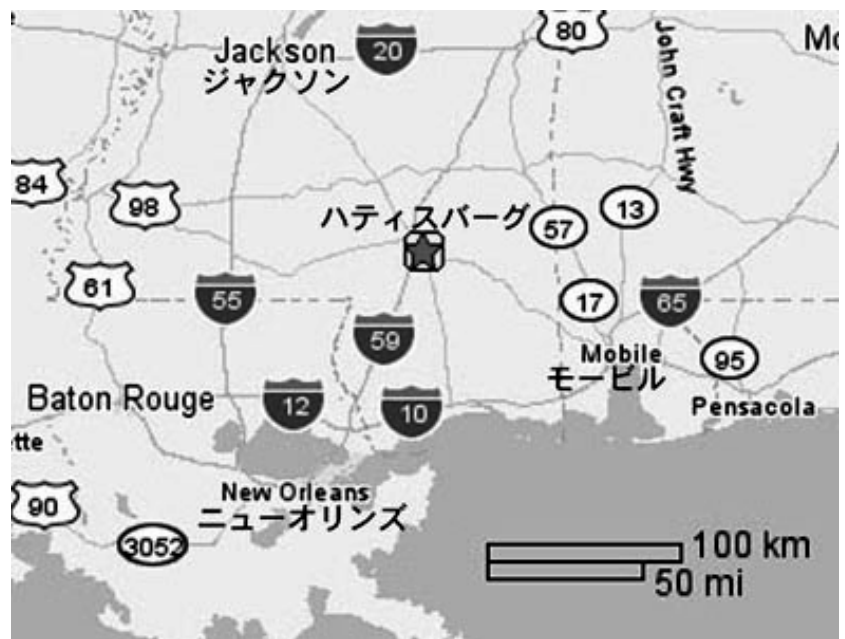

図 1 USM のあるハティスバーグの位置

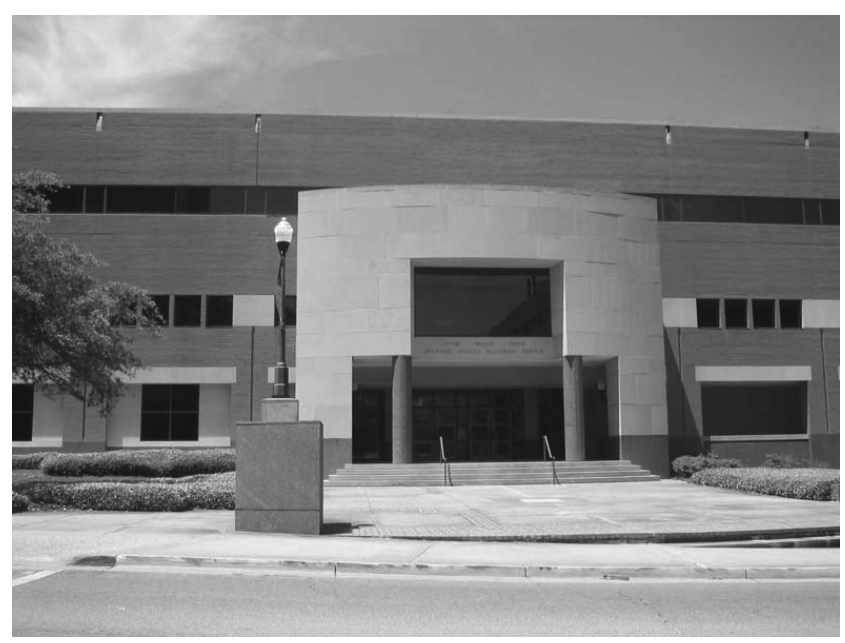

図 2 Shelby F. Thames Polymer Science Research Center

しており，米国の中でも高水準の高分子科学に関した研 究・教育活動が行なわれている. 1998 年 4 月に再建され た Shelby F. Thames Polymer Science Research Center (以下「PSRC」と略する) という綺麗な 3 階建ての建物内 に教官のオフィス, 研究室, 講議室, 会議室があり, そこ でほとんどの研究・教育活動が行なわれる（図 2). 建物 の名前についている Shelby F. Thames 教授は, USM の 高分子科学の研究・教育の発展に大変大きな貢献をしてき 
ている方である。現在はUSM の学長であり PSRC の教官 としても籍を置いている。Dr. Thames は環境に調和した 塗料開発の第一人者であり, 塗料の研究, 製造, 販売を行 なうUSM 発の会社の創設も行っている。そこで製造した 塗料が，ワシントン DC にあるペンタゴンの建築，修繕時 に使用されていたという話は，ここUSM では有名である.

\section{PSRC 内の研究分野と設備}

「School of Polymers and High Performance Materials」 には 16 名の教官がおり，機能性高分子材料の合成，コー ティング材料, エラストマー, フィルム, 電解質膜, 高分 子複合材料などに関した研究を行なっている.このように 教官の専門分野は多岐に渡っており, 詳しい研究内容につ いては，学科のホームページを参照して頂きたい（参考資 料 1).

PSRC 内には，共有の電子顕微鏡 (SEM，TEM)，原子 間力顕微鏡, 各種クロマトグラフィー，フーリエ変換赤外 分光装置 (FT-IR), 動的固体粘弾性測定機 (DMA), 示 差走查熱量測定機（DSC）, 熱重量減少測定機（TGA）な どの装置があり専門スタッフが操作法の説明や操作補助を 行なっている. またマシーンショップ（機械加工場）とエ レクトロニクスショップがあり，それぞれの専門スタッフ が機械加工，電子機械作製の研究支援を行なっている. 日 本の大学の技官の方々と同様に, とても頼りになる存在で ある。

この学科は MRSEC (Materials Research Science and Engineering Centers) という米国の材料研究センターの 一つに指定されており，学科として「反応に誘起された高 分子フィルム (Response-Driven Polymeric Film)」に関 する研究プロジェクトを推進している ${ }^{2}$.この研究プロジェ クトには, 広い専門分野をまたぐ研究が必要なため PSRC 内のそれぞれの研究グループは「フィルム形成」,「モルフォ ロジー」,「レオロジー」,「分離」,「スペクトロスコピー」, 「合成」,「サーモメカニカル」というクラスターに分けら れ，それぞれの役割を担当する事になっている．そのため 研究グループ間での共同研究, 装置の貸し借りが頻繁に行 なわれ，他の研究グループとの交流が盛んである.

その他 PSRC 内には, 産学連携の推進, 州内企業の技 術向上を目的に，州議会により設立された MPI（The Mississippi Polymer Institute) という組織が入居している. MPI では射出成形や押出成形などのプラスチック成形加 工技術，コーティング技術のコンサルティング，従業員研 修サービスを行なっている．教官もアドバイザーとして加 わる仕組みとなっている。

筆者の所属している Otaigbe 教授の研究グループでは (図 3), 高分子複合材料の粘弾性特性と力学強度特性に関 する研究を行なっている. Otaigbe 教授が化学工学を専門 にしてきているためだと思われるが，必要であれば材料の 合成から，成形機を用いた成形加工まで研究グループ内で 行なっている. 研究プロジェクトは, カーボンやクレイを 使用したナノコンポジット材料, ポリウレタン水分散液の レオロジー制御，ポリリン酸エステルガラスを用いた複合 材料, 反応射出成形による高分子複合材料, 大豆夕ンパク 質の成形性・学特性の改善などである. 研究グループで

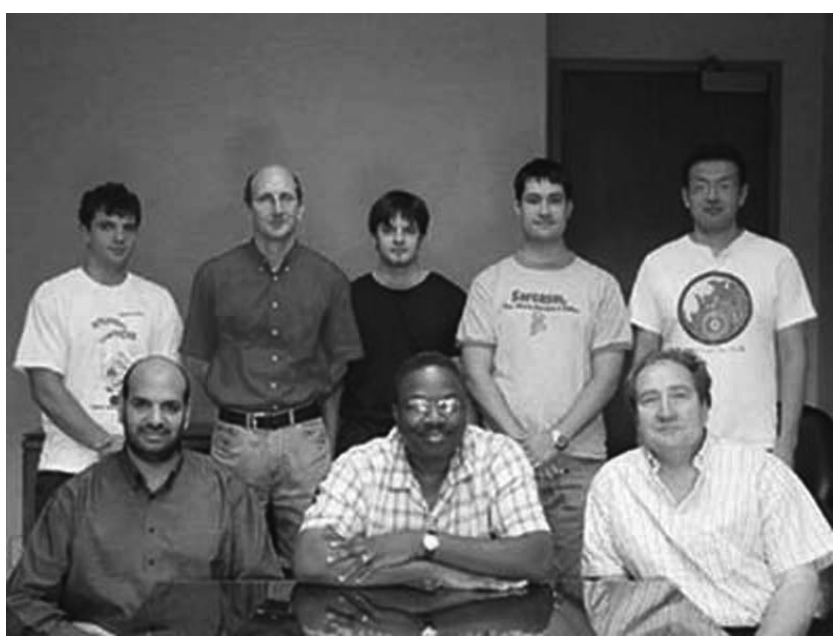

図 3 Otaigbe 教授の研究グループ (Otaigbe 教授がナイ ジェリア出身, ロシア人, エジプト人, フランス人, 日本人, アメリカ人と非常にユニークな構成)

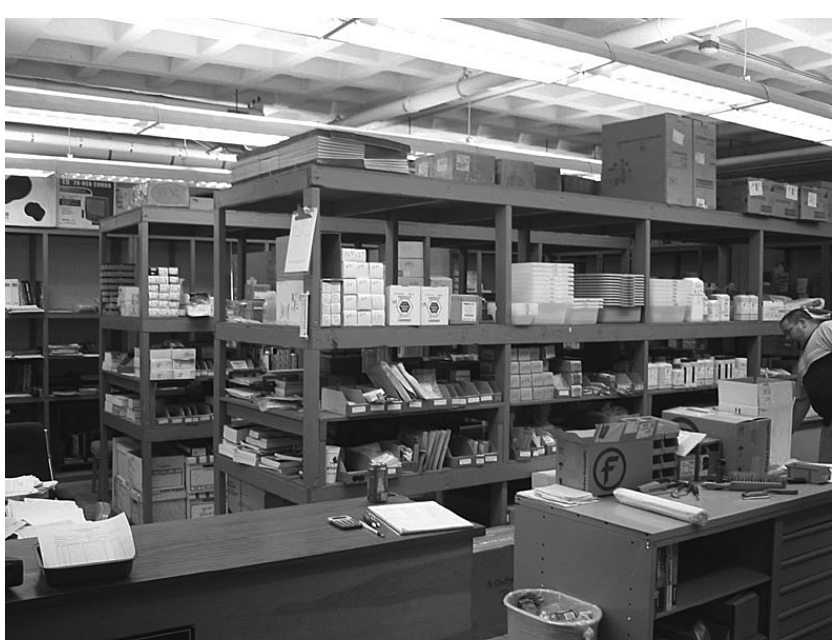

図 4 Science Storeroom の様子

は押出機, 射出成形機, 小型混錬機, 圧縮成形機, 回転レ オメーター，伸長レオメーター，毛細管型レオメーター, DMA, TGA, DSC, 光学顕微鏡, 焼成炉などを所有している.

\section{4. 研究環境について}

USM の PSRC でポストドクター（博士研究員）として 実際に研究を行うという点では，日本の大学で高分子材料 の研究開発をしていた時と大きな違いは感じられない。例 えば，電子顕微鏡などの共同利用装置も管理者から一度レ クチャーを受ける事で自由に使用可能となる. 他の研究室 にある装置も両方の教官に話を通す事が出来れば使用させ てもらえる，液体窒素，各種ガス，水を使用したい時は, 建物内で容易に手に入れる事ができる。試薬や備品も理化 学機器を扱う代理店のカタログを使って発注し，日本で使 用していた物と同様の物が入手できる. 文献複写も電子図 書館や USM 図書館を通して入手する事が可能である.コ ピーなども自由に使用可能である（おそらく研究グループ が負担していると思うが)。インターネットは研究室では 24 時間使用可能であり，カギを持っていれば土，日，祝 日に関わらず一日中研究室に出入りする事が可能である. 
便利なのが Science Storeroom という，いわば学部共同 の物品貯蔵部屋である (図 4). そこには研究で頻繁に使 用される物品が貯蔵，管理されている（フラスコ，攪拌子， ポンプオイルなど品数多数). 物品を切らした時には, Science Storeroom まで行けば容易に入手できるので, 納品 を待たずしてすぐに研究を開始する事ができる.

その他面白いと思ったのは，ここの学部生は 2,3 年生 のうちから研究室に出入りしている事である. 彼等は研究 室で主に院生やポスドクの実験の手伝い, 研究室の整頓な どをしてくれている，研究室で手伝いをするのは学部生の 単位取得のカリキュラムになっているらしい。週 40 時間 程度までの時給は出るらしく, 生活費程度は稼ぐ事が可能 のようだ.

\section{5. 留学生について}

「School of Polymers and High Performance Materials」 の学部生には, やはりアメリカ人が多いが, 大学院生, ポ スドクには，アメリカ以外の国から来ている人が多く見受 けられる. 中国, インドから来ている人が多く, その他フ ランス, ドイッ, ロシア, エジプト, タイ, 日本から留学 している方々と会った. それぞれ海外から来て, 高分子材 料の研究を行っている者同士, 仲良くなるのはそう難しく 無いと感じる. 大学内には留学生を支援するための専門の オフィスが設けられており, 渡米前のビザに必要な書類の 発行, USM に来てからの各種手続きを支援してくれる.

語学学習に関しては, USM には ELI(English Language Institute）という大学付属の集中英語コースがあり, 有料 ではあるが, 週 5 時間から 25 時間まで選択し, ニーズに
合わせて英語を学習する事が可能である.

\section{6. その他の USM 施設}

最後に研究生活を支援してくれるUSM 施設を紹介させ て頂きたい．学内には「Payne Center」という名前の立 派な運動施設があり, 体育館, プール, ウェイトトレーニ ング, エクササイズ用スタジオ, シャワーやサウナ設備が利 用可能である. 学生やスタッフだと月 15 ドル程度で自由 に使用できる。学外訪問者は一回 5 ドルで使用可能である。 学内にある郵便局は大変便利である. 荷物宅配時にア パートを留守にしていると, わざわざ遠くの中央郵便局ま で取りに行かなくてはならないので, 学内で荷物の発送, 特に受取りができる事は, 単身で留学している者にとって は有り難い.

食堂は学内に数力所ある. 日替わりメニューも楽しめる 立食形式（ビュッフェ）の食堂, ピザ, ハンバーガー, サ ンドイッチを扱うファーストフード店, 日本でも人気のカ フェなどがある. 大学近くには中華料理, 日本料理屋もあ り「野菜炒め定食」を食べる事も可能であった.

\section{謝辞}

本稿を作成するにあたって，ご協力を頂戴した Douglas Iverson 氏に謝意を表します。

\section{参 考 資 料}

1) http : //www.psrc.usm.edu/index.html

2) http ://www.mrsec.org/home/ 